\title{
No Association between Polymorphisms of Vitamin D and Oxytocin Receptor Genes and Autistic Spectrum Disorder in a Sample of Turkish Children
}

\author{
Sevcan Tug Bozdogan ${ }^{1, *}$, Meryem Ozlem Kutuk ${ }^{2, *}$, Evren Tufan $^{3}$, Zuhal Altıntaş ${ }^{4}$, Gülhan Orekici Temel ${ }^{5}$, \\ Fevziye Toros $^{6}$ \\ ${ }^{1}$ Department of Medical Genetics, School of Medicine, Çukurova University, Adana, ${ }^{2}$ Department of Child and Adolescent Psychiatry, School \\ of Medicine, Başkent University, Adana, ${ }^{3}$ Department of Child and Adolescent Psychiatry, School of Medicine, Abant Izzet Baysal University, \\ Bolu, Departments of ${ }^{4}$ Medical Genetics, ${ }^{5}$ Biostatistics and Medical Informatics, ${ }^{6}$ Child and Adolescent Psychiatry, School of Medicine, Mersin \\ University, Mersin, Turkey
}

\begin{abstract}
Objective: Autism spectrum disorder (ASD) is a neurodevelopmental disorder characterized by impairment in social skills and communication with repetitive behaviors. Etiology is still unclear although it is thought to develop with interaction of genes and environmental factors. Oxytocin has extensive effects on intrauterine brain development. Vitamin D, affects neural development and differentiation and contributes to the regulation of around 900 genes including oxytocin receptor gene. In the present study, the contribution of D vitamin receptor and oxytocin receptor gene polymorphisms in the development of ASD in Turkish community was investigated. To our knowledge, this is the first study examining these two associated genes together in the literature.

Methods: Eighty-five patients diagnosed with ASD according to DSM-5 who were referred to outpatient clinics of Child and Adolescent Psychiatry of Başkent University and Mersin University and 52 healthy, age and gender-matched controls were included in the present study. Vitamin D receptor gene rs731236 (Taq1), rs2228570 (Fok1), rs1544410 (Bsm1), rs7975232 (Apa1) polymorphisms and oxytocin receptor gene rs1042778 and rs2268493 polymorphisms were investigated using real time polymerase chain reaction method.

Results: No significant difference between groups in terms of distribution of genotype and alleles in each of polymorphisms for these genes could be found.

Conclusion: Knowledge of genes and polymorphisms associated with the development of ASD may be beneficial for early diagnosis and future treatment. Further studies with larger populations are required to demonstrate molecular pathways which may play part in the development of ASD in Turkey.
\end{abstract}

KEY WORDS: Autism spectrum disorder; Oxytocin receptors; Calcitriol receptors; Genetic polymorphism.

\section{INTRODUCTION}

Autism spectrum disorder (ASD) is a neurodevelopmental disorder involving deficits in social interaction along with restricted interests and repetitive and stereotypic patterns of behavior. The estimated prevalence of

Received: May 9, 2017 / Revised: July 7, 2017

Accepted: July 8, 2017

Address for correspondence: Sevcan Tug Bozdogan, MD

Department of Medical Genetics, Cukurova University, Saricam, Adana 01100, Turkey

Tel: +90-5052347082, Fax: +90-322-338694

E-mail: sevcantb@gmail.com

ORCID: https://orcid.org/0000-0003-3853-8212

*These authors contributed equally to this work.
ASD based on the 2014 National Health Interview Survey was $2.24 \%$ with a more than three-fold increase since 2000. The male to female ratio is shown to be $4: 1{ }^{1)}$ The widely reported increase of ASD cases has stimulated research in etiology through the recent decades.

It is currently accepted that ASD has substantial heritability. Specifically, twin studies have shown a concordance of $70.0 \%$ to $90.0 \%$ among monozygotic twins, with much lower rates among dizygotic twins. ${ }^{3,4)}$ The risk for a newborn child is increased more than ten times when a previous sibling has an ASD. ${ }^{5)}$ Genome-wide linkage and association studies have been done to search for susceptibility genes for ASD and several candidate genes have been showed to be involved in ASD. ${ }^{6-11)}$

(ㄷ) This is an Open-Access article distributed under the terms of the Creative Commons Attribution Non-Commercial License (http://creativecommons.org/licenses/by-nc/4.0) which permits unrestricted non-commercial use, distribution, and reproduction in any medium, provided the original work is properly cited. 
Although many genetic mechanisms have been elaborated in the pathogenesis of ASD, the complete picture of ASD pathogenesis at biochemical and genetic levels remains to be identified. Supporting this view, the known genetic variations account for only $10.0 \%$ to $20.0 \%$ of patients with ASD. ${ }^{6,12,13)}$ Therefore, rather than a single causative factor, the combination and interplay of heritability and environmental risk factors may be important in etiology of ASD. ${ }^{13)}$

Among those factors, vitamin $\mathrm{D}$ and oxytocin may be important. $^{14-16)}$ Vitamin D is important for neuronal embriyogenesis and development, immune neuromodulation, anti-oxidation, anti-apoptosis, neuronal differentiation and genetic regulation. ${ }^{14)}$ Some studies suggest that children with ASD may be deficient in vitamin D and that incidence of ASD may increase in offspring of mothers with vitamin $\mathrm{D}$ deficiency in pregnancy. ${ }^{15)}$ The observations that vitamin $D$, in its active form, contributes to regulation and expression of approximately 900 genes, most of which play role in brain development as well as its interactions with serotonergic metabolism and oxytocinmay support this view. ${ }^{15,17,18)}$ Contrarily, vitamin D metabolism may also be affected in other pediatric neuro-developmental and neuro-psychiatric disorders and its abnormalities may not be specific to ASD. ${ }^{19-21)}$ Also, rather than absolute vitamin D levels, receptor polymorphisms may be more important in neuropsychiatric functioning. ${ }^{21)}$

Oxytocine (OXT) is a neuropeptide related with social behavior, affiliation/attachment, social memory, reward and reactivity to social stress in mammals. ${ }^{22-26)}$ Recent studies suggest that OXT may also be important for social cognition both in healthy humans as well as those with ASD and that exogenous applications of OXT may affect social behaviors albeit temporarily. ${ }^{16,25-31)}$

Genes for OXT and its receptor also contain vitamin D responsive elements (VDREs) changing their function (i.e., both production and response). ${ }^{17,18,32,33)}$ VDREs colocalize with OXT in hypothalamic neurons, both interact with serotonergic metabolism and genetic variations in both have been associated with ASD; suggesting a role in etiology. ${ }^{17,18,32-40)}$ On the other hand; OXT levels as well as receptor polymorphisms may display their effects independent of the ASD diagnosis ${ }^{41,42)}$ and changes in $V D R$ were also reported for patients with ADHD. ${ }^{43)}$

Converging lines of evidence suggest that vitamin D, $V D R$, OXT and its receptors may play roles in social behaviors. ${ }^{15-18,22-43)}$ As far as we are aware, no study up to now attempted to evaluate polymorphisms in both VDR and OXTR in ASD. Therefore, we aimed to evaluate the contribution of $V D R$ and OXTR gene polymorphisms in the development of autism spectrum disorder in a Turkish sample.

\section{METHODS}

\section{Study Center, Time Frame and Ethics}

This study was conducted between January 2015 and January 2017 in the Child and Adolescent Psychiatry outpatient departments of Baskent University Faculty of Medicine and Mersin University Faculty of Medicine. Age- and gender-matched healthy controls were enrolled among elementary school students from two schools located in the epidemiological catchment areas of both departments. The study protocol has been approved by local ethics committee of the study center with a protocol number of MEU 2014/209. Parental informed assent and verbal assent of the children (if applicable) were procured prior to study entry. All of the study procedures were in accordance with the Declaration of Helsinki and local laws and regulations.

\section{Inclusion and Exclusion Criteria}

Three to 18 year-old, patients with non-regressive, simplex-ASD (i.e., only index case among offspring), ${ }^{44)}$ according to the Diagnostic and Statistical Manual of Mental Disorders, fifth edition (DSM-5) criteria, ${ }^{45)}$ with a score of $>29.5$ (i.e., above cut-off for ASD) in the Turkish version of the Childhood Autism Rating Scale, ${ }^{46)}$ without known genetic syndromes (i.e., Down's syndrome, fragile X syndrome, Rett syndrome) or comorbid intellectual disability (as evaluated with developmental tests or Turkish version of the Wechsler Intelligence Scale for Children, revised edition along with clinical interviews) were included. The patients included those with autistic disorder, Asperger's disorder and pervasive developmental disorder-not otherwise specified (PDD-NOS) according to DSM fourth edition, text revision (DSM-IV-TR) criteria. The patients should also be free of of comorbid chronic medical and neurological disorders. Healthy controls should be free of life-time psychopathology as evaluated via Turkish version of the Kiddie Schedule for Affective Disorders and Schizophrenia for School Aged Children-Present/Lifetime 
Version (K-SADS-PL). ${ }^{47)}$ Parental informed consent and verbal assent of children (if applicable) were necessary for inclusion.

\section{Power Analysis}

Under a multiplicative model with significance level of 0.05 (not corrected for multiple comparisons), a disease prevelance of $1.0 \%$, genotype relative risk of 1.2 , disease allele frequency of $20.0 \%$ and at $1: 1$ case-to-control ratio we would need 2,000 cases for $70.0 \%$ power. ${ }^{48-50)}$ Within the time-frame and considering our load of patients with ASD we settled for 100 cases with ASD and 100 controls (i.e., $41.0 \%$ power). In the end we could enroll 85 patients with ASD and 52 controls leading to a power of approximately $30.0 \%$.

\section{Laboratory Analysis}

In both groups, DNA was extracted from peripheral blood transferred to ethilen dianmin acetic acid tubes. Genomic DNA was extracted from peripheral blood by using GF-1 blood DNA extraction kit (Vivantis Technologies $^{\text {TM }}$, Oceanside, CA, USA) according to the manufacturer's instructions. VDR rs731236 (Taq1), rs2228570 (Fok1), rs1544410 (Bsm1) rs7975232 (Apa1) polymorphisms and OXTR rs1042778 and rs2268493 polymorphisms genotyping was performed with the TaqMan $^{\circledR}$ SNP Genotyping Assay (Applied Biosystems, Foster City, CA, USA). The polymerase chain reaction (PCR) reactions were carried out in a total volume of $25 \mu \mathrm{L}$ containing TaqMan ${ }^{\circledR}$ Genotyping Master Mix, TaqMan ${ }^{\circledR}$
Genotyping AssayMix, DNase-free water and genomic DNA. The PCR conditions were 10 minutes at $95^{\circ} \mathrm{C}$, followed by 40 cycles at $95^{\circ} \mathrm{C}$ for 15 seconds and $60^{\circ} \mathrm{C}$ for 1 minutes. The 96-well ABI 7500 Fast Real-Time PCR system was applied (Applied Biosystems).

\section{Statistical Analysis}

In statistical analysis, SPSS ver. 11.5 (SPSS Inc., Chicago, IL, USA.) and MedCalc Statistical software version 10.4 (MedCacl Software bvba, Ostend, Belgium) programs were used. For comparisons between groups, chi square test, $t$ test for independent samples and MannWhitney $U$ tests were used and results were evaluated with $95.0 \%$ confidence intervals and $p<0.05$ was considered statistically significant. All comparisons were two-tailed. Bonferroni adjustment was undertaken for

Table 1. Sociodemographic variables of children with autism spectrum disorder (ASD) and healthy controls

\begin{tabular}{lccc}
\hline \multicolumn{1}{c}{ Variable } & ASD $(\mathrm{n}=85)$ & $\begin{array}{c}\text { Healthy controls } \\
(\mathrm{n}=52)\end{array}$ & $p$ value \\
\hline $\begin{array}{l}\text { Age }(\mathrm{yr}) \\
\text { Sex }\end{array}$ & $7.38 \pm 4.01$ & $7.46 \pm 3.87$ & 0.903 \\
$\quad$ Male & $72(84.7)$ & $39(75.0)$ & 0.160 \\
$\quad$ Female & $13(15.3)$ & $13(25.0)$ & \\
Mother's age (yr) & $34.98 \pm 6.51$ & $38.94 \pm 6.35$ & $0.001^{*}$ \\
Father's age (yr) & $38.37 \pm 9.38$ & $37.41 \pm 14.14$ & 0.634 \\
Number of siblings & $2(1-2)$ & $2(1-3)$ & $0.007^{*}$ \\
Order of birth & $2(2-3)$ & $1(1-2)$ & $0.002^{*}$ \\
\hline
\end{tabular}

Values are presented as mean \pm standard deviation, number $(\%)$, or median (range).

*Mann-Whitney $U$ or $t$ tests.

Table 2. Genotype and allele frequencies of children with autism spectrum disorder (ASD) and healthy controls for vitamin D and oxytocine receptors

\begin{tabular}{|c|c|c|c|c|c|c|c|c|c|c|c|c|c|}
\hline \multirow{3}{*}{ Gene } & \multirow{3}{*}{ SNP } & \multicolumn{6}{|c|}{ Genotype frequency } & \multirow{3}{*}{$p^{*}$} & \multicolumn{4}{|c|}{ Allele frequency } & \multirow{3}{*}{$p^{*}$} \\
\hline & & \multicolumn{3}{|c|}{ Healthy control } & \multicolumn{3}{|c|}{ ASD } & & \multicolumn{2}{|c|}{ Healthy control } & \multicolumn{2}{|c|}{ ASD } & \\
\hline & & $1 / 1$ & $1 / 2$ & $2 / 2$ & $1 / 1$ & $1 / 2$ & $2 / 2$ & & 1 & 2 & 1 & 2 & \\
\hline$V D R$ & $\begin{array}{l}\text { rs731236 } \\
\text { (Taq1) }\end{array}$ & $21(40.4)$ & $28(53.8)$ & $3(5.8)$ & $37(43.5)$ & $35(41.2)$ & $13(15.3)$ & 0.157 & $70(67.3)$ & $34(32.7)$ & $109(64.1)$ & $61(35.9)$ & 0.590 \\
\hline$V D R$ & $\begin{array}{l}\text { rs2228570 } \\
(\text { Fok } 1)\end{array}$ & $4(7.7)$ & $20(38.5)$ & $28(53.8)$ & $5(5.9)$ & $31(36.5)$ & $49(57.6)$ & 0.870 & $28(26.9)$ & $76(73.1)$ & $41(24.1)$ & 129 (75.9) & 0.604 \\
\hline$V D R$ & $\begin{array}{l}\text { rs1544410 } \\
\text { (Bsm1) }\end{array}$ & $6(11.5)$ & $26(50.0)$ & $20(38.5)$ & $11(12.9)$ & $40(47.1)$ & $34(40.0)$ & 0.938 & $38(36.5)$ & $66(63.5)$ & $62(36.5)$ & $108(63.6)$ & 0.991 \\
\hline$V D R$ & $\begin{array}{l}\text { rs7975232 } \\
\text { (Apa1) }\end{array}$ & $0(0.0)$ & $35(67.3)$ & $17(32.7)$ & $2(2.4)$ & $56(65.9)$ & $27(31.8)$ & 0.537 & $35(33.7)$ & $69(66.3)$ & $60(35.3)$ & $110(64.7)$ & 0.782 \\
\hline OXTR & rs1042778 & $19(36.5)$ & $28(53.8)$ & $5(9.6)$ & $30(35.3)$ & $40(47.1)$ & 15 (17.6) & 0.419 & $66(63.5)$ & $38(36.5)$ & $100(58.8)$ & 100 (58.8) & 0.446 \\
\hline OXTR & rs2268493 & $0(0.0)$ & $20(38.5)$ & 32 (61.5) & $6(7.1)$ & 28 (32.9) & $51(60.0)$ & 0.138 & $20(19.2)$ & $84(80.8)$ & $40(23.5)$ & 130 (76.5) & 0.404 \\
\hline
\end{tabular}

Values are presented as number (\%).

*Hardy-Weinberg test. 
multiple comparisons. Whether population distribution was balanced in ASD and control groups was analyzed with Hardy-Weinberg test.

\section{RESULTS}

Within the specified time-frame 85 patients with a mean age of $7.38 \pm 4.01$ years $(84.7 \%$ male) and 52 healthy controls with a mean age of $7.46 \pm 3.87$ years (75.0\% male) could be enrolled. The groups were similar in terms of mean age and gender ratios $(p=0.903$ and 0.160; respectively) (Table 1 ).

Control subjects were significantly more likely to be first born and had more siblings. Their mothers were also significantly older than those of children with ASD.

Genotyping results of patients andhealthy controls included in the study are summarized in Table 2.

VDR-Taq I displayed Hardy-Weinberg equilibrium only in patients with $\operatorname{ASD}(p=0.30)$ but did not display it in controls $(p=0.03)$. All other SNPs of $V D R$ were in equilibrium for both controls and patients with ASD. For OXTR SNPs only rs2268493 was not in equilibrium and only for controls $(p=0.02)$. All other SNPs were in equilibrium.

No significant differences could be found between groups in terms of genotypes and allelles.

\section{DISCUSSION}

This multi-center, cross-sectional, case-control study on polymorphisms of VDR and OXTR in age- and gender-matched patients with ASDs and healthy controls could not find a significant difference between groups.

ASD is a heterogeneous disorder that is characterized by impaired social communications/interactions, and restricted, repetitive behaviors. Latest prevalence figures cited were as high as 1 in 88 which denotes an increase of $600.0 \%$ from 1970s. The cause of this increase is still not entirely known, although earlier recognition and detection of milder cases on the spectrum were frequently listed as major contributors. ${ }^{51,52)}$

The increase in ASD prevalence has stimulated research on its genetic basis. Changes in at least 440 genes were reported in etiology. Of these, $7.0 \%$ to $20.0 \%$ include changes in number of copies, $5.0 \%$ to $7.0 \%$ involve polymorphisms in a single gene, and $5.0 \%$ are single gene mutations associated with metabolic diseases. ${ }^{6,53)}$
Changes in levels of vitamin $\mathrm{D}$ as well as genetic variations in its metabolism as well as interaction with oxytocin were posited to play a role in ASD etiology. ${ }^{14,15)}$ Vitamin $\mathrm{D}$, in its active form plays role in brain development and functioning ${ }^{1718)}$ and interacts with serotonin and oxytocin, $15,21,33,39)$ supporting a potential role in ASD. Previous reviews suggested that genetic variations affecting vitamin $\mathrm{D}$ levels and functioning could play a role in ASD. ${ }^{54)}$ Schmidt et al. ${ }^{40)}$ reported that VDR polymorphisms especially. Taql and Bsml could be associated with ASD risk. ${ }^{40)}$ In another, recent study from Turkey, Fokl, Taql, and Bsml genotypes for VDR differed significantly between children with ASD and healthy controls. ${ }^{39)}$ An earlier study however, failed to find an association. ${ }^{43)}$ In our study we also could not find an association between SNP at $V D R$ (Taql, Fokl, Bsml, and Apal) and a diagnosis of ASD. This negative result may be due to low power of our study. Indeed, a post-hoc power analysis revealed that we could only achieve $30.0 \%$ power to refute the null hypothesis. Alternatively, our sampling method for simplex, non-regressive ASD cases may be inadequate (i.e., dependence on personal reports and pediatric consultations, lack of genetic testing for specific syndromes). Also, there may be false negatives among our sample due to "stoppage phenomenon" ${ }^{7,44)}$ The patients as a whole varied in severity and included those who would be diagnosed with either autistic disorder, Asperger syndrome or PDD-NOS as per DSM-IV-TR criteria. This heterogeneity may have also affected our results. VDR Taql and OXTR rs2268493 polymorphisms were also not in equilibrium among controls and this may have affected the results.

Variations in OXT function are also suggested among etiologies for ASDs. ${ }^{16,23,29-31)}$ SNPs in OXTR are known to affect social functions ${ }^{37,41)}$ even without a formal diagnosis of ASD. Vitamin D also interacts with oxytocin in neural functioning. ${ }^{1718)} \mathrm{SNP}$ rs 1042778 at OXTR may increase social impairment in ASD $^{36,37)}$ while rs2268493 may affect speech and repetitive movements in addition to social skills in ASD. ${ }^{37,38)}$ As for discrete diagnostic entities, rs2268493 was found to be associated with Asperger syndrome ${ }^{55)}$ while rs2268493 and rs1042778 were found to be associated with ASD. ${ }^{37,38,56)}$ However, a study from Japan failed to replicate the association of those polymorphisms with ASD. ${ }^{57)}$ We also failed to replicate this association. This may be due to heterogeneous and lim- 
ited samples as well as low power. Our results should be confirmed with further studies on larger samples.

Finally, controls in our sample had more siblings and were more likely to be first born offspring of their mothers while patients with ASD had significantly younger mothers. While the first finding may be related to the "stoppage phenomenon" and the stresses of caring for a child with ASD, the second observation needs explanation. ${ }^{44)}$ We tried to sample simplex families which may select especially for copy number variations (CNVs) in etiology. ${ }^{2-7,44)}$ While increasing parental age is known to be related with changes in germ cells and de novo CNVs, recent findings suggest that early parenthood may also be related with changes in germ cell lines. ${ }^{58,59)}$ Our findings may reflect those observations although lack of genetic testing of parents in our sample precludes more definite hypotheses. The effects of early-parenthood on risk for ASD in offspring should be evaluated with further studies.

This multi-center, case-control study of SNPs in OXTR and $V D R$ in ASD failed to find a significant association. The results may be affected by limited sample size and power and inadequate sampling of simplex cases. Further studies on larger ASD samples, preferably from differing geographical regions of Turkey are needed for confirmation of our results.

\section{Acknowledgments}

This project was supported by TUBITAK (The Scientific and Technological Research Council of Turkey, Project No: 115S864).

\section{REFERENCES}

1. Zablotsky B, Black LI, Maenner MJ, Schieve LA, Blumberg SJ. Estimated prevalence of autism and other developmental disabilities following questionnaire changes in the 2014 National Health Interview Survey. Natl Health Stat Report 2015; (87):1-20.

2. Ronemus M, lossifov I, Levy D, Wigler M. The role of de novo mutations in the genetics of autism spectrum disorders. Nat Rev Genet 2014;15:133-141.

3. Tchaconas A, Adesman A. Autism spectrum disorders: a pediatric overview and update. Curr Opin Pediatr 2013;25: 130-144.

4. Szatmari P. Is autism, at least in part, a disorder of fetal programming? Arch Gen Psychiatry 2011;68:1091-1092.

5. Constantino JN, Zhang Y, Frazier T, Abbacchi AM, Law P. Sibling recurrence and the genetic epidemiology of autism. Am J Psychiatry 2010;167:1349-1356.
6. Gupta AR, State MW. Recent advances in the genetics of autism. Biol Psychiatry 2007;61:429-437.

7. Freitag CM. The genetics of autistic disorders and its clinical relevance: a review of the literature. Mol Psychiatry 2007;12: $2-22$.

8. Veenstra-VanderWeele J, Cook EH Jr. Molecular genetics of autism spectrum disorder. Mol Psychiatry 2004;9:819-832.

9. Vorstman JA, Staal WG, van Daalen E, van Engeland $\mathrm{H}$, Hochstenbach PF, Franke L. Identification of novel autism candidate regions through analysis of reported cytogenetic abnormalities associated with autism. Mol Psychiatry 2006; 11:1, 18-28.

10. Woodbury-Smith M, Bilder DA, Morgan J, Jerominski L, Darlington T, Dyer T, et al. Combined genome-wide linkage and targeted association analysis of head circumference in autism spectrum disorder families. I Neurodev Disord 2017;9:5.

11. Hamedani SY, Gharesouran J, Noroozi R, Sayad A, Omrani MD, Mir A, et al. Ras-like without CAAX 2 (RIT2): a susceptibility gene for autism spectrum disorder. Metab Brain Dis 2017;32:751-755.

12. Abrahams BS, Geschwind DH. Advances in autism genetics: on the threshold of a new neurobiology. Nat Rev Genet 2008;9:341-355.

13. Hens K, Peeters H, Dierickx K. The ethics of complexity. Genetics and autism, a literature review. Am J Med Genet B Neuropsychiatr Genet 2016;171B:305-316.

14. Gentile I, Zappulo E, Militerni R, Pascotto A, Borgia G, Bravaccio C. Etiopathogenesis of autism spectrum disorders: fitting the pieces of the puzzle together. Med Hypotheses 2013;81:26-35.

15. Patrick RP, Ames BN. Vitamin D hormone regulates serotonin synthesis. Part 1: relevance for autism. FASEB J 2014;28: 2398-2413.

16. Lee YJ, Oh SH, Park C, Hong M, Lee AR, Yoo HJ, et al. Advanced pharmacotherapy evidenced by pathogenesis of autism spectrum disorder. Clin Psychopharmacol NeurosCi 2014; 12:19-30.

17. Wang TT, Tavera-Mendoza LE, Laperriere D, Libby E, MacLeod NB, Nagai Y, et al. Large-scale in silico and microarray-based identification of direct 1,25-dihydroxyvitamin D3 target genes. Mol Endocrinol 2005; 19:2685-2695.

18. McCann JC, Ames BN. Is there convincing biological or behavioral evidence linking vitamin $D$ deficiency to brain dysfunction? FASEB J 2008;22:982-1001.

19. Goksugur SB, Tufan AE, Semiz M, Gunes C, Bekdas M, Tosun $\mathrm{M}$, et al. Vitamin $D$ status in children with attention-deficit-hyperactivity disorder. Pediatr Int 2014;56:515-519.

20. Çelik G, Taş D, Tahiroğlu A, Avci A, Yüksel B, Çam P. Vitamin $D$ deficiency in obsessive-compulsive disorder patients with pediatric autoimmune neuropsychiatric disorders associated with streptococcal infections: a case control study. Noro Psikiyatr Ars 2016;53:33-37.

21. Föcker M, Antel J, Ring S, Hahn D, Kanal Ö, Öztürk D, et al. 
Vitamin D and mental health in children and adolescents. Eur Child Adolesc Psychiatry 2017. doi: 10.1007/s00787-0170949-3. [Epub ahead of print]

22. Landgraf R, Neumann ID. Vasopressin and oxytocin release within the brain: a dynamic concept of multiple and variable modes of neuropeptide communication. Front Neuroendocrinol 2004;25:150-176.

23. Carter CS. Neuroendocrine perspectives on social attachment and love. Psychoneuroendocrinology 1998;23:779-818.

24. Young LJ, Wang Z. The neurobiology of pair bonding. Nat Neurosci 2004;7:1048-1054.

25. Domes G, Heinrichs M, Gläscher J, Büchel C, Braus DF, Herpertz SC. Oxytocin attenuates amygdala responses to emotional faces regardless of valence. Biol Psychiatry 2007; 62:1187-1190.

26. Domes G, Heinrichs M, Michel A, Berger C, Herpertz SC. Oxytocin improves "mind-reading" in humans. Biol Psychiatry 2007;61:731-733.

27. Guastella AJ, Mitchell PB, Dadds MR. Oxytocin increases gaze to the eye region of human faces. Biol Psychiatry 2008; 63:3-5.

28. Guastella AJ, Mitchell PB, Mathews F. Oxytocin enhances the encoding of positive social memories in humans. Biol Psychiatry 2008;64:256-258.

29. Hollander E, Novotny S, Hanratty M, Yaffe R, DeCaria CM, Aronowitz BR, et al. Oxytocin infusion reduces repetitive behaviors in adults with autistic and Asperger's disorders. Neuropsychopharmacology 2003;28:193-198.

30. Hollander E, Bartz J, Chaplin W, Phillips A, Sumner J, Soorya $\mathrm{L}$, et al. Oxytocin increases retention of social cognition in autism. Biol Psychiatry 2007;61:498-503.

31. Andari E, Duhamel JR, Zalla T, Herbrecht E, Leboyer M, Sirigu A. Promoting social behavior with oxytocin in high-functioning autism spectrum disorders. Proc Natl Acad Sci U S A 2010;107:4389-4394.

32. Toell A, Polly P, Carlberg C. A/l natural DR3-type vitamin D response elements show a similar functionality in vitro. Biochem J 2000:352:301-309.

33. Prüfer K, Jirikowski GF. 1.25-Dihydroxyvitamin D3 receptor is partly colocalized with oxytocin immunoreactivity in neurons of the male rat hypothalamus. Cell Mol Biol (Noisy-legrand) 1997;43:543-548.

34. Ma WJ, Hashii M, Munesue T, Hayashi K, Yagi K, Yamagishi $\mathrm{M}$, et al. Non-synonymous single-nucleotide variations of the human oxytocin receptor gene and autism spectrum disorders: a case-control study in a Japanese population and functional analysis. Mol Autism 2013;4:22.

35. Wu S, Jia M, Ruan Y, Liu J, Guo Y, Shuang M, et al. Positive association of the oxytocin receptor gene (OXTR) with autism in the Chinese Han population. Biol Psychiatry 2005;58:74-77.

36. Lerer E, Levi S, Salomon S, Darvasi A, Yirmiya N, Ebstein RP. Association between the oxytocin receptor (OXTR) gene and autism: relationship to Vineland Adaptive Behavior Scales and cognition. Mol Psychiatry 2008; 13:980-988.

37. Campbell DB, Datta D, Jones ST, Batey Lee E, Sutcliffe JS, Hammock EA, et al. Association of oxytocin receptor (OXTR) gene variants with multiple phenotype domains of autism spectrum disorder. J Neurodev Disord 2011;3:101-112.

38. Yrigollen CM, Han SS, Kochetkova A, Babitz T, Chang JT, Volkmar FR, et al. Genes controlling affiliative behavior as candidate genes for autism. Biol Psychiatry 2008;63:911916.

39. Coşkun S, Şimşek Ş, Camkurt MA, Çim A, Çelik SB. Association of polymorphisms in the vitamin $D$ receptor gene and serum 25-hydroxyvitamin D levels in children with autism spectrum disorder. Gene 2016;588:109-114.

40. Schmidt RJ, Hansen RL, Hartiala J, Allayee H, Sconberg JL, Schmidt LC, et al. Selected vitamin D metabolic gene variants and risk for autism spectrum disorder in the CHARGE Study. Early Hum Dev 2015;91:483-489.

41. Ayaz AB, Karkucak M, Ayaz M, Gokce S, Kayan E, Güler EE, et al. Oxytocin system social function impacts in children with attention-deficithyperactivity disorder. Am J Med Genet B Neuropsychiatr Genet 2015;168:609-616.

42. Sasaki T, Hashimoto K, Oda Y, Ishima T, Kurata T, Takahashi J, et al. Decreased levels of serum oxytocin in pediatric patients with attention deficit/hyperactivity disorder. Psychiatry Res 2015;228:746-751.

43. Yan J, Feng J, Craddock N, Jones IR, Cook EH Jr, Goldman D, et al. Vitamin D receptor variants in 192 patients with schizophrenia and other psychiatric diseases. Neurosci Lett 2005; 380:37-41.

44. Sanders S. Multiplex-simplex comparisons. In: Volkmar FR, editor. Encyclopedia of autism spectrum disorders. New York:Springer;2013. p. 1960.

45. American Psychiatric Association. Diagnostic and Statistical Manual of Mental Disorders, Fifth Edition (DSM-5). Arlington, VA:American Psychiatric Association;2013. 947 p.

46. İncekaş Gassaloğlu S, Baykara B, Avcil S, Demiral Y. Validity and reliability analysis of Turkish version of childhood autism rating scale. Turk Psikiyatri Derg 2016;27:266-274.

47. Gökler B, Ünal F, Pehlivantürk B, Kültür EÇ, Akdemir D, Taner Y. Reliability and validity of schedule for affective disorders and schizophrenia for school age children-present and lifetime version-Turkish version (K-SADS-PL-T). Turk J Child Adolesc Ment Health 2004;11:109-116.

48. Hong EP, Park JW. Sample size and statistical power calculation in genetic association studies. Genomics Inform 2012; 10:117-122.

49. Skol AD, Scott LJ, Abecasis GR, Boehnke M. Joint analysis is more efficient than replication-based analysis for two-stage genome-wide association studies. Nat Genet 2006;38:209213.

50. Purcell S, Cherny SS, Sham PC. Genetic power calculator: design of linkage and association genetic mapping studies of complex traits. Bioinformatics 2003;19:149-150. 
51. Autism and Developmental Disabilities Monitoring Network Surveillance Year 2008 Principal Investigators; Centers for Disease Control and Prevention. Prevalence of autism spectrum disorders--Autism and Developmental Disabilities Monitoring Network, 14 sites, United States, 2008. MMWR Surveill Summ 2012;61:1-19.

52. Fombonne E. The prevalence of autism. JAMA 2003;289:8789.

53. Schaaf $\mathrm{CP}$, Zoghbi HY. Solving the autism puzzle a few pieces at a time. Neuron 2011;70:806-808.

54. Kočovská E, Fernell E, Billstedt E, Minnis H, Gillberg C. Vitamin D and autism: clinical review. Res Dev Disabil 2012; 33:1541-1550.

55. Di Napoli A, Warrier V, Baron-Cohen S, Chakrabarti B. Genetic variation in the oxytocin receptor (OXTR) gene is associated with Asperger Syndrome. Mol Autism 2014;5:48.
56. Francis SM, Kim SJ, Kistner-Griffin E, Guter S, Cook EH, Jacob S. ASD and genetic associations with receptors for oxytocin and vasopressin-AVPR1A, AVPR1B, and OXTR. Front NeurosCi 2016;10:516.

57. Liu X, Kawamura Y, Shimada T, Otowa T, Koishi S, Sugiyama $\mathrm{T}$, et al. Association of the oxytocin receptor (OXTR) gene polymorphisms with autism spectrum disorder (ASD) in the Japanese population. J Hum Genet 2010;55:137-141.

58. Hvolgaard Mikkelsen S, Olsen J, Bech BH, Obel C. Parental age and attention-deficit/hyperactivity disorder (ADHD). Int J Epidemiol 2017;46:409-420.

59. McGrath JJ, Petersen L, Agerbo E, Mors O, Mortensen PB, Pedersen CB. A comprehensive assessment of parental age and psychiatric disorders. JAMA Psychiatry 2014;71:301309. 